\title{
Pengaruh Penambahan Co-Doping Mg/La Terhadap Karakterisasi Tioz Sebagai Fotoelektroda
}

\author{
Nurul Azmi, Ismail Ismail, dan Mursal ${ }^{*}$ \\ Jurusan fisika, Universitas Syiah Kuala, Banda Aceh, Indonesia, 23111 \\ Email:mursal@unsyiah.ac.id
}

Diterima (31 Agustus 2020), Direvisi (18 Januari 2021)

\begin{abstract}
The effect of $\mathrm{Mg} / \mathrm{La}$ co-doping addition on the characteristics of $\mathrm{TiO}_{2}$ as photoelectrode have been studied. This study aims to investigate the effect of $\mathrm{Mg} / \mathrm{La}$ co-doping concentration on the characteristics of TiO2. This study aims investigate the effect of $\mathrm{Mg} / \mathrm{La}$ co-doping concentration on the characteristics of $\mathrm{TiO}_{2}$. $\mathrm{Mg} / \mathrm{La}$ was varied from $0 \% \mathrm{~mol}, 0.4 / 0.6 \% \mathrm{~mol}$, and $0.6 / 0.4 \% \mathrm{~mol}$. Synthesis of TiO2 co-doping Mg/La was done by sol gel method. The resulting of powder pure $\mathrm{TiO}_{2}$ and co-doping $\mathrm{Mg} / \mathrm{La}$ was made to paste, and was deposited on a glass substrate with a size of $2.5 \times 2.5 \mathrm{~cm}$ and sintered at $600^{\circ} \mathrm{C}$ for 1 hour. $\mathrm{Mg} / \mathrm{La}$ co-doped $\mathrm{TiO}_{2}$ layers were characterized using XRD, UV-Vis, and FTIR spectrometers. The results showed that $\mathrm{TiO}_{2}$ was the mosdominan phase appeared in pure $\mathrm{TiO}_{2}$ sample. The phase of $\mathrm{MgO}, \mathrm{MgTiO}_{3}, \mathrm{Mg}_{2} \mathrm{TiO}_{4}$, and $\mathrm{La}_{2} \mathrm{O}_{3}$ were found in $\mathrm{Mg} / \mathrm{La}$ co-doped $\mathrm{TiO}_{2}$ samples. The crystal size of $\mathrm{Mg} / \mathrm{La}$ co-doped $\mathrm{TiO}_{2}$ was varied from 8.85 to $7.70 \mathrm{~nm}$. In this research, we obtained that the energy gap was varied from 3.52 to $3.5 \mathrm{eV}$ depent on codopant concentration. FTIR measurement showed groups of Ti-O, Ti-O-Ti, Ti-O-O, and $\mathrm{H}-\mathrm{O}$.
\end{abstract}

Keywords: Co-doping Mg/La, photoelectrode, Sol Gel method, $\mathrm{TiO}_{2}$.

Abstrak. Telah dilakukan pengaruh penambahan co-doping $\mathrm{Mg} / \mathrm{La}$ terhadap karakteristik $\mathrm{TiO}_{2}$ sebagai fotoelektroda. Penelitian ini bertujuan untuk mempelajari pengaruh variasi konsentrasi co-doping $\mathrm{Mg} / \mathrm{La}$ terhadap karakterisasi $\mathrm{TiO}_{2}$. Perbandingan $\mathrm{Mg} / \mathrm{La}$ divariasikan $0 \%$ mol, 0,4/0,6\% mol, dan 0,6/0,4\% mol. Sinteta $\mathrm{TiO}_{2}$ co-doping $\mathrm{Mg} / \mathrm{La}$ dilakukan dengan metode sol gel. Serbuk $\mathrm{TiO}_{2}$ murni dan co-doping $\mathrm{Mg} / \mathrm{La}$ yang dihasilkan dijadikan pasta, dan dideposisikan di atas substrat dengan ukuran 2,5 x 2,5 cm dan disintering pada suhu $600^{\circ} \mathrm{C}$ selama 1 jam. Lapisan $\mathrm{TiO}_{2}$ co-doping $\mathrm{Mg} / \mathrm{La}$ dikarakterisasi menggunakan XRD, spektrometer UV-Vis, dan spectrometer FTIR. Hasil penelitian menunjukkan fasa-fasa $\mathrm{TiO}_{2}$ paling dominan muncul pada $\mathrm{TiO}_{2}$ murni. Setelah dilakukan co-doping $\mathrm{Mg} / \mathrm{La}$ fasa-fasa yang muncul $\mathrm{MgO}, \mathrm{MgTiO}_{3}, \mathrm{Mg}_{2} \mathrm{TiO}_{4}$, dan $\mathrm{La}_{2} \mathrm{O}_{3}$. Ukuran kristal dari $\mathrm{TiO}_{2}$ co-doping $\mathrm{Mg} / \mathrm{La}$ berkisar 8,85 - 7,70 nm. Energi gap $\mathrm{TiO}_{2}$ co-doping $\mathrm{Mg} / \mathrm{La}$ yang diperoleh pada penelitian ini berkisar antara 3,52-3,5 eV. Penambahan co-doping $\mathrm{Mg} / \mathrm{La}$ dapat mengurangi energi gap. Hasil Pengukuran FTIR menunjukkan adanya pembentukan gugus Ti-O, Ti-O-Ti, Ti$\mathrm{O}-\mathrm{O}$, dan $\mathrm{H}-\mathrm{O}$.

Kata kunci: Co-doping $\mathrm{Mg} / \mathrm{La}$, fotoelektroda, metode sol gel, $\mathrm{TiO}_{2}$.

\section{PENDAHULUAN}

Sel surya saat ini menjadi salah satu devais alternatif yang dapat digunakan sebagai penghasil energi listrik. Sel surya dapat mengkonversikan energi matahari menjadi energi listrik secara langsung dengan memanfaatkan sifat fotofoltaik dari material. Salah satu jenis sel surya yang sedang dikembangkan adalah Dye Sensitized Solar Cells (DSSC). DSSC menjadi pilihan karena memiliki keunggulan dalam segi biaya yang relatif rendah dan proses fabrikasi lebih singkat [1]. DSSC tersusun dari beberapa bagian penting seperti subtrat, fotoelektroda, dye, elektrolit, dan kounter 
elektroda. Fotoelektroda menjadi komponen penting pada DSSC, yang berfungsi sebagai fotokatalis. Fotoelektroda yang baik memiliki stabilitas terhadap fotokorosi dan energi celah pita yang relatif rendah sehingga memudahkan terjadi penyerapan energi foton lebih banyak dalam spektrum cahaya tampak [2].

Salah satu semikonduktor yang biasa digunakan sebagai fotoelektroda adalah $\mathrm{TiO}_{2} . \mathrm{TiO}_{2}$ dipilih karena memiliki potensi tinggi sebagai fotooksidasi, bersifat fotokatalis, ekonomis, dan mudah didapatkan. Namun $\mathrm{TiO}_{2}$ memiliki kekurang ketika diaplikasikan dalam DSSC, yaitu masih mudah terjadi rekombinasi elektron. Hal ini disebabkan energi gap dari $\mathrm{TiO}_{2}$ masih tergolong tinggi [3]. Permasalahan tersebut dapat diatasi dengan cara mendoping $\mathrm{TiO}_{2}$ dengan material lain. Pendopingan dilakukan untuk mengubah morfologi, struktur, sifat listrik, dan optik dari bahan induk $[3,4]$. Pendopingan pada umumnya dilakukan dengan menambahkan satu jenis material dopan (misalnya $\mathrm{Mg}$ atau La) ke dalam $\mathrm{TiO}_{2}$. Namun untuk meningkatkan kinerja $\mathrm{TiO}_{2}$ sebagai fotokatalitik maka dilakukan pendopingan dengan dua jenis material dopan ke dalam $\mathrm{TiO}_{2}$, yang dikenal dengan istilah co-doping. Co-doping dapat meningkatkan fotoaktifitas $\mathrm{TiO}_{2}$ ketika terpapar cahaya tampak dibandingkan dengan $\mathrm{TiO}_{2}$ murni [5].

Shakir et al., (2018) mencoba $\mathrm{TiO}_{2}$ doping $\mathrm{Mg}$. Doping $\mathrm{Mg}$ dapat menurunkan energi gap dari 3,2 eV menjadi 2,8 eV [6]. Variasi komposisi doping $\mathrm{Mg}$ juga mempengaruhi ukuran kristal dari $\mathrm{TiO}_{2}$ yaitu dari 53,92 nm menjadi 49,23 nm [7]. Variasi suhu anneling juga dapat mempengaruhi energi gap, semakin besar suhu anneling yang diberikan maka energi gap yang dihasilkan semakin kecil [8]. Hal yang sama juga berlaku pada pendopingan La, dimana penambahan doping La juga dapat menurunkan energi gap dari 2,98 eV menjadi 2,75 eV [9]. Hasil penelitian Rafieh et al., (2017) menunjukan co-doping $\mathrm{Mg} / \mathrm{la}$ dapat memperkecil ukuran kristal dari $\mathrm{TiO}_{2}$ dan meningkatkan efesiensi DSSC ketika diaplikasikan [10]. Dalam tulisan ini, peneliti menyajikan hasil penelitian tentang $\mathrm{TiO}_{2} \quad$ co-doping $\mathrm{Mg} / \mathrm{La}$ dengan memvariasikan konsentrasi doping $\mathrm{Mg} / \mathrm{La}$ dengan menggunakan metode sol gel.

\section{METODE PENELITIAN}

Proses deposisi $\mathrm{TiO}_{2}$ murni dan codoping dilakukan dengan metode sol gel [11]. Bahan utama yang digunakan Titanium (IV) isopropoxide (Sigma Aldrich 97\%), Magnesium Acetate Tethahydrate (Sigma Aldric 99\%), Lanthanum (III) Acetate hydrate (sigma aldric 98\%). Pelarut yang digunakan adalah isopropanol, aquades, $\mathrm{HCl}$ dan ethanol. Variasi konsentrasi co-doping $\mathrm{Mg} / \mathrm{La}$ merujuk pada Tabel 1. Titanium (IV) isopropanol dicampurkan dengan isopropanol dan aquades sebanyak 50:5 (v:v) sampai larutan menjadi berubah menjadi putih. Selanjutnya co-doping Magnesium Acetate Tethahydrate dan Lanthanum (III) Acetate hydrate dicampur dan di tambah $\mathrm{HCl}(1 \mathrm{ml})$ selanjutnya distir selama 2 jam. Larutan yang diperoleh diendapkan selama 12 jam pada suhu ruang sampai berubah menjadi gel. Selanjutnya sampel dikeringkan dalam oven dan dilakukan pencucian sebanyak dua kali dengan ethanol, kemudian sampel dikeringkan dalam oven dengan suhu $60{ }^{\circ} \mathrm{C}$. Sampel yang dihasilkan dari proses pengeringan disinterring selama 5 jam dengan suhu $500{ }^{\circ} \mathrm{C}$. Proses pembuatan pasta $\mathrm{TiO}_{2}$ murni dan co-doping $\mathrm{Mg} / \mathrm{La}$ yaitu dengan menambahkan serbuk $\mathrm{TiO}_{2}$ murni dan yang telah didoping dengan asam acetate $(0.76 \mathrm{ml})$, Ethanol $(10 \mathrm{ml})$ dan Triton $\mathrm{X}-100$ dua tetes dan distir sampai sampel menjadi pasta. Pasta yang dihasilkan dideposisikan di atas substrat dengan ukuran $2.5 \times 2.5 \mathrm{~cm}$, kemudian disinterring pada suhu $600{ }^{\circ} \mathrm{C}$ dengan waktu tahan 1 jam. 
Tabel 1. Variasi konsentrasi co-doping $\mathrm{Mg} / \mathrm{La}$

\begin{tabular}{ccccc}
\hline No & Nama Sampel & $\begin{array}{c}\text { Konsentrasi } \\
\text { Titanium (IV) } \\
\text { Isopropoxide }(\% \\
\text { mol) }\end{array}$ & $\begin{array}{c}\text { Konsentrasi Magnesium } \\
\text { Acetate Tethahydrat }(\% \\
\text { mol) }\end{array}$ & $\begin{array}{c}\text { Konsentrasi } \\
\text { Lanthanum (III) } \\
\text { Acetate Hydrate }(\% \\
\text { mol) }\end{array}$ \\
\hline 1 & A & 4 & - & - \\
\hline 3 & B & 4 & 0,4 & 0,6 \\
\hline
\end{tabular}

Karakterisasi X-Ray Diffraction (XRD) dilakukan untuk melihat struktur kristal dan ukuran butir kristal $\mathrm{TiO}_{2}$ co-doping $\mathrm{Mg} / \mathrm{La}$. Sifat optic dari $\mathrm{TiO}_{2}$ co-doping $\mathrm{Mg} / \mathrm{La}$ dianalisis berdasarkan spektrum UV-Vis. Selanjutnya pengujian FTIR dilakukan untuk melihat gugus fungsi dari sampel yang terbentuk setelah proses pendopingan.

\section{HASIL DAN PEMBAHASAN}

\section{Hasil Analisis XRD}

Pola difraksi sinar-X (XRD) dari $\mathrm{TiO}_{2}$ co-doping $\mathrm{Mg} / \mathrm{La}$ diperlihatkan Gambar 1. Pada gambar terlihat fasa-fasa yang muncul yaitu fasa $\mathrm{TiO}_{2}$ pada sudut $2 \theta=25,26,48,02$, $37,49,53$, dan 55 dengan bidang hkl 110, 211, 021, 202, 130, dan 113 terlihat pada $\mathrm{TiO}_{2}$ murni. Pola difraksi setelah dilakukan co-doping $\mathrm{Mg} / \mathrm{La}$ dengan konsentasi yang bervariasi menghasilkan fasa $\mathrm{TiO}_{2}$ dan fasa $\mathrm{MgO}$ pada sudut $2 \theta=36,90$ dan 62,02 . Fasa $\mathrm{MgTiO}_{3}$ pada sudut $2 \theta=38,52$ dengan bidang hkl 309 dan fasa $\mathrm{Mg}_{2} \mathrm{TiO}_{4}$ muncul pada sudut $2 \theta=54,22$ dan 56. Sedangkan fasa $\mathrm{La}_{2} \mathrm{O}_{3}$ muncul pada sudut $2 \theta=26,36$ dan 30,58. Puncak dfraksi dari ketiga sampel yang paling banyak muncul adalah $\mathrm{TiO}_{2}$, sedangkan puncak difraksi $\mathrm{MgO}, \mathrm{MgTiO}_{3}$, $\mathrm{Mg}_{2} \mathrm{TiO}_{4}$, dan $\mathrm{La}_{2} \mathrm{O}_{3}$ muncul pada intensitas yang sangat rendah. Hal ini membuktikan bahwa dengan adanya co-doping $\mathrm{Mg} / \mathrm{La}$ mengubah fasa induk dari $\mathrm{TiO}_{2}$ terlihat puncak dari $\mathrm{TiO}_{2}$ semakin melebar sehingga mengakibatkan distorsi kisi pada struktur $\mathrm{TiO}_{2}$ dan mempengaruhi kristalinitas dari $\mathrm{TiO}_{2}$ [10], [12].

Ukuran kristal diperoleh dari hasil perhitungan kuantitatif menggunakan metode scherrer dari Persamaan 1, diperoleh hasil seperti pada Tabel 2.

$$
D=\frac{0.95 \lambda}{B \cos \theta}
$$

Dimana D adalah ukuran butir rata-rata dari sampel $(\AA), \quad \lambda$ adalah panjang gelombang dari sinar- $x$ yang digunakan XRD $(\AA)$, B adalah pelebaran setengah puncak difraksi maksimum yaitu Full Width at Half Maximum (FWHM), $\theta$ adalah sudut puncak difraksi sinar-X. 


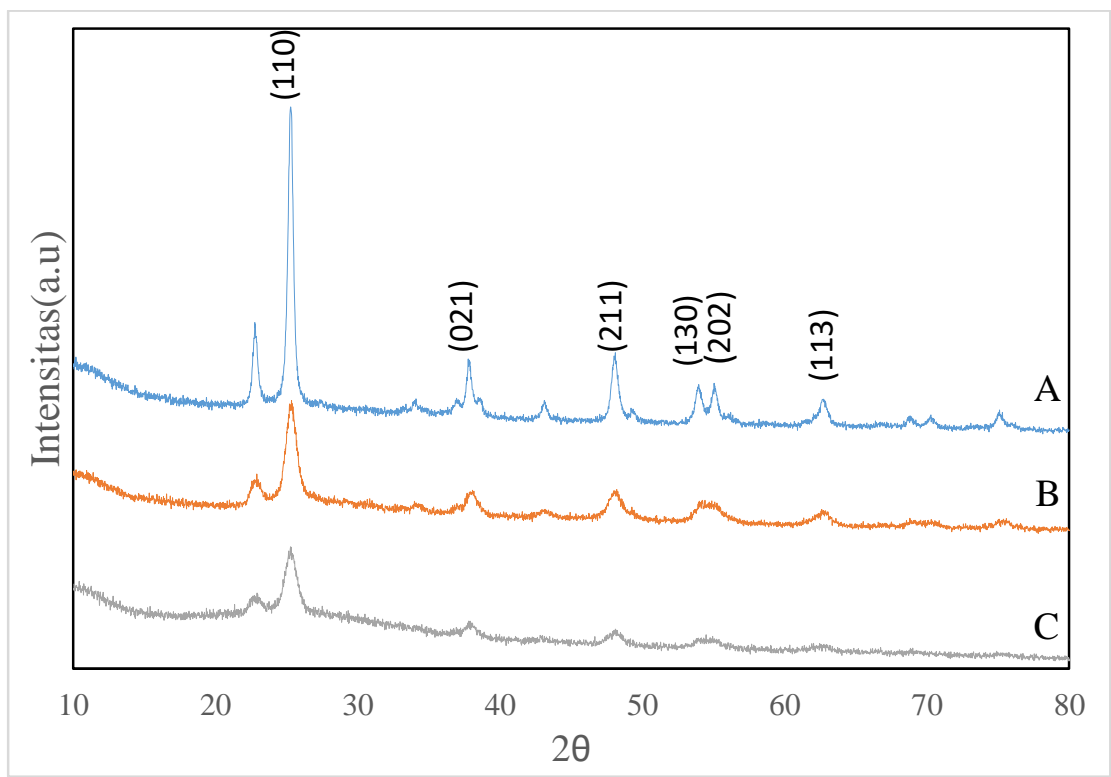

Gambar 1. Pola difraksi sinar-X lapisan $\mathrm{TiO}_{2}$ co-doping $\mathrm{Mg} / \mathrm{La}\left(\mathrm{A} . \mathrm{TiO}_{2}\right.$ murni, $\mathrm{B} . \mathrm{TiO}_{2}$ co-doping $\mathrm{Mg} / \mathrm{La} \mathrm{0.4/0.6 \%}$ mol, dan C. $\mathrm{TiO}_{2}$ co-doping $\mathrm{Mg} / \mathrm{La} \mathrm{0,6/0,4 \%} \mathrm{mol).}$

Berdasarkan hasil perhitungan terlihat ukuran butir kristal $\mathrm{TiO}_{2}$ murni 19,08 nm. Penambahan co-doping $\mathrm{Mg} / \mathrm{La}$ mengakibatkan ukuran butir kristal dari $\mathrm{TiO}_{2}$ menjadi 8,85 dan $7,70 \mathrm{~nm}$, seperti diperlihatkan dalam Tabel 2. Perubahan ukuran butir kristal yang semakin kecil (dalam kisaran nanometer) dapat meningkatkan kemampuan absorpsi semikonduktor sebagai fotokatalis oksida [8]. Ukuran butir kristal dari material juga sangat dipengaruhi oleh ukuran jari-jari ionik material yang digunakan. Ukuran jari-jari ionik $\mathrm{Mg}^{2+}$ yaitu $0.72 \AA$, jari-jari ionik $\mathrm{La}^{3+}$ yaitu $1,03 \AA$, sedangkan jari-jari ionik $\mathrm{Ti}^{4+}$ yaitu $0.61 \AA[10,11]$.

Tabel 2. Ukuran butir kristal dari $\mathrm{TiO}_{2}$ co-doping $\mathrm{Mg} / \mathrm{La}$

\begin{tabular}{ccccc}
\hline No & Nama Sampel & $2 \theta\left({ }^{\circ}\right)$ & FWHM & Ukuran Kristal $(\mathrm{nm})$ \\
\hline 1 & A & 25.2580 & 0.4512 & 19.08 \\
2 & B & 25.3058 & 0.9716 & 8.85 \\
3 & C & 25.2780 & 1.1160 & 7.70 \\
\hline
\end{tabular}

Tabel 3. Perhitungan Energi gap lapisan $\mathrm{TiO}_{2}$ co-doping $\mathrm{Mg} / \mathrm{La}$

\begin{tabular}{clcc}
\hline No & Nama Sampel & $\lambda_{\text {cutoff }}(\mathrm{nm})$ & Energi gap $(\mathrm{eV})$ \\
\hline 1 & A & 352 & 3.52 \\
2 & B & 353 & 3.51 \\
3 & C & 354 & 3.5 \\
\hline
\end{tabular}




\section{Analisis Sifat Optik}

Sifat optik $\mathrm{TiO}_{2}$ co-doping $\mathrm{Mg} / \mathrm{La}$ diperoleh dari hasil pengujian menggunakan spektrometer UV-Vis Shimadzu UV-1700 dengan rentang panjang gelombang yang diberikan 300-800 nm. Berdasarkan spektrum absorpsi tersebut, diperoleh panjang gelombang dan nilai $\lambda_{\text {cutoff }}$, sehingga dapat ditentukan nilai energi gap menggunakan persamaan 2 .

$$
E=\frac{h c}{\lambda}
$$

Dimana $\mathrm{E}$ adalah energi foton $(\mathrm{eV}), \mathrm{h}$ adalah konstanta Planck $\left(6,626 \times 10^{-34} \mathrm{~J} . \mathrm{s}\right), \mathrm{c}$ adalah kecepatan cahaya $\left(3 \times 10^{8} \mathrm{~m} / \mathrm{s}\right)$, dan $\lambda$ adalah panjang gelombang cahaya yang datang (m).

Variasi konsentrasi $\mathrm{Mg} / \mathrm{La}$ sangat mempengaruhi energi gap seperti ditunjukan pada Tabel 3. Energi gap pada $\mathrm{TiO}_{2}$ murni yaitu 3,52 eV. Namun setelah dilakukan co-doping $\mathrm{Mg} / \mathrm{La}$ maka energi gap turun sebesar 0,01. Hal ini disebabkan energi gap dari $\mathrm{Mg}$ dan $\mathrm{La}$ lebih kecil dibandingkan dengan energy gap $\mathrm{TiO}_{2}$, sehingga penambahan co-diping $\mathrm{Mg} / \mathrm{La}$ mempersempit celah enegi $\mathrm{TiO}_{2}$. Shakir et al, (2018) mendapatkan bahwa penambahan doping $\mathrm{Mg}$ menurunkan energi gap dari 3,2 eV menjadi
2,9 eV [6]. Doping La juga dapat menurunkan energi gab $\mathrm{TiO}_{2}$ menjadi 2,75 eV. Penambahan co-doping $\mathrm{Mg} / \mathrm{La}$ dapat menurunkan energi gap dari $\mathrm{TiO}_{2}$ sebesar $0.05 \mathrm{eV}[10,11,13]$.

\section{Analisa FTIR}

Spektrum FTIR pada lapisan $\mathrm{TiO}_{2}$ codoping $\mathrm{Mg} / \mathrm{La}$ terlihat pada Gambar 2. Spektrum yang dihasilkan menampilkan rantai polimer $\mathrm{Ti}-\mathrm{O}-\mathrm{Ti}$ pada bilangan gelombang $471 \mathrm{~cm}^{-1}$, Gugus $\mathrm{TiO}_{2}$ stretching muncul pada bilangan gelombang 516,92 $\mathrm{cm}^{-1}$, dan Ti-O terlihat pada bilangan gelombang $789 \mathrm{~cm}^{-1}$. Vibrasi pita Ti-O-O teridentifikasi pada panjang gelombang 693 $\mathrm{cm}^{-1}$. Pelebaran pita bilangan gelombang $3000-3600 \mathrm{~cm}^{-1}$ membentuk gugus $\mathrm{OH}$. Karakterisasi mode vibrasi O-H terlihat pada bilangan gelombang $3414 \mathrm{~cm}^{-1}$ dan $1635 \mathrm{~cm}^{-}$ 1 dan Ti-OH telihat pada bilangan gelombang $3417 \mathrm{~cm}^{-1}$. Co-doping $\mathrm{Mg} / \mathrm{La}$ membentuk gugus La3-TO pada bilangan gelombang 1300-1700 $\mathrm{cm}^{-1}$, gugus $\mathrm{La}_{3}-\mathrm{TO}$ terbentuk pada permukaan $\mathrm{H}_{2} \mathrm{O}$ [9]. Gambar 2 menunjukkan dengan adanya co-doping $\mathrm{Mg} / \mathrm{La}$ gugus $\mathrm{O}-\mathrm{H}$ semakin banyak muncul dan gugus $\mathrm{O}-\mathrm{H}$ juga muncul pada bilangan gelombang 2000-3600 $\mathrm{cm}^{-1}$ namun puncaknya terjadi pelebaran seperti terlihat pada sampel C .

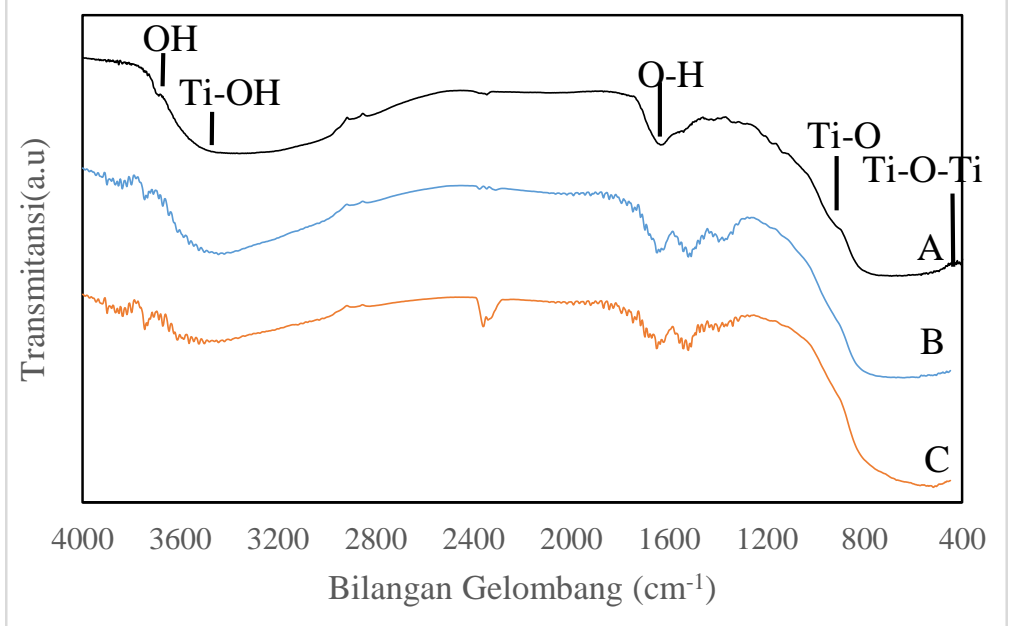

Gambar 2. Spektrum FTIR $\mathrm{TiO}_{2}$ co-doping $\mathrm{Mg}-\mathrm{La}$ (A. $\mathrm{TiO}_{2}$ murni, $\mathrm{B}$. $\mathrm{TiO}_{2}$ co-doping $\mathrm{Mg} / \mathrm{La}$ 0.4/0.6\% mold an $\mathrm{C}$. $\mathrm{TiO}_{2}$ co-doping $\left.\mathrm{Mg} / \mathrm{La} 0.6 / 0.4 \% \mathrm{~mol}\right)$. 


\section{KESIMPULAN}

Berdasarkan hasil penelitian didapatkan bahwa variasi komposisi codoping $\mathrm{Mg} / \mathrm{La}$ yang diberikan meningkatkan derajat kekristalan $\mathrm{TiO}_{2} . \mathrm{TiO}_{2}$ co-doping $\mathrm{Mg} / \mathrm{La}$ mempengaruhi ukuran kristal $\mathrm{TiO}_{2}$ dari 19,08 menjadi 7,70 $\mathrm{nm}$ dengan seiring penambahan konsentrasi $\mathrm{Mg} / \mathrm{La}$. Pengurangan ukuran butir kristal mengakibatkan munculnya pori-pori sehingga memperluas permukaan sampel. Penambahan co-doping $\mathrm{Mg} / \mathrm{La}$ juga mempengaruhi energi gap menjadi lebih kecil dari 3,52 menjadi $3,5 \mathrm{eV}$, sehingga $\mathrm{TiO}_{2}$ berpotensi sebagai fotoelektroda dan bersifat fotoaktif. Co-doping $\mathrm{Mg} / \mathrm{La}$ memperluas gugus rantai polimer $\mathrm{O}-\mathrm{H}$, sehingga gugus $\mathrm{O}-\mathrm{H}$ paling banyak muncul.

\section{UCAPAN TERIMAKASIH}

Penulis mengucucapkan terimakasih kepada Syarifah Fathmiyah, S.Si dari laboratorium material FMIPA, Nurhazanah, ST dari laboratorium rekayasa Teknik kimia, dan Muttaqin, M.Pd dari laboratorium kimia FKIP Universitas Syiah Kuala atas bantuannya dalam pengujian sampel.

\section{DAFTAR PUSTAKA}

[1] D. Y. Kim dan M. Kang, "Diversi Fi cation of Photoelectric Effi ciency on DSSCs Assembled According to the Change of Coating Layers of Px-TiO Films", Journal Material Chemistry and Physics. vol. 136, pp. 947-953, 2012.

[2] C. Zhang, S. Chen, L. Mo, Y. Huang, H. Tian, L. Hu, Z. Huo, S. Dai, F. Kong, dan X. Pan, "Charge Recombination and Band-Edge Shift in the Dye-Sensitized",. The Journal of Physical Chemistry. pp. 1641816424, 2011.

[3] C. Dette, M. A. Pérez-Osorio, C. S. Kley, P. Punke, C. E. Patrick, P.
Jacobson, F. Giustino, S. Jung, dan K. Kern, " $\mathrm{TiO}_{2}$ Anatase with a Bandgap in the Visible Region", Nano Letters. 2014.

[4] Y. Duan, N. Fu, Q. Zhang, Y. Fang, X. Zhou, dan Y. Lin "Influence of Sn Source on the Performance of DyeSentized Solar Cells Based on SnDoped $\mathrm{TiO}_{2}$ Photoanodes: A Strategy for Choosing an Appropriate Doping Source", Electrochimica Acta. no. March, 2013.

[5] G. S. Mital danT. Manoj, "A Review of $\mathrm{TiO}_{2}$ Nanoparticles", Chinese Science Bulletin. vol. 56, no. 16, pp. 1639-1657, 2011.

[6] S. Shakir, M. Abd-ur-rehman, K. Yunus, dan M. Iwamoto, "Fabrication of Un-Doped and Magnesium Doped $\mathrm{TiO}_{2}$ FILMS by Aerosol Assisted Chemical Vapor Deposition for Dye Sensitized Solar Cells", Journal of Alloys Compounds. vol. 737, pp. 740747, 2018.

[7] Mursal, Ismail, V. Yuniar, dan E. Yufita, "Structural and Optical Properties of $\mathrm{MgO}$-doped $\mathrm{TiO}_{2}$ Prepared by Sol-Gel Method", Coff. AIC. vol. 110007, no. March, 2020.

[8] W. Angreni, E. Yusibani, dan Mursal, "Metode Sol Gel $\mathrm{MgTiO}_{3}$ Thin Films Synthesis by Sol Gel Method", Journal of Physics Aceh. vol. 7, no. 2, pp. 2-3, 2018.

[9] Y. Huang, J. Cao, F. Kang, S. You, C. Chang, dan Y. Wang, "High Selectivity of Visible-Light-Driven La-doped $\mathrm{TiO}_{2}$ Photocatalysts for NO Removal," pp. 2555-2565, 2017.

[10] A. I. Rafieh, P. Ekanayake, A. Ling, and C. Ming, "Effects of ionic radii of co-dopants ( $\mathrm{Mg}, \mathrm{Ca}, \mathrm{Al}$ and $\mathrm{La}$ ) in $\mathrm{TiO}_{2}$ on performance of dyesensitized solar cells," Sol. Energy, vol. 141, pp. 249-255, 2017.

[11] A. Rajour Tanyi, "Enhanced Efficiency of Dye-Sensitized Solar 
Cells Based on $\mathrm{Mg}$ and La Co-Doped Tio 2 Photoanodes", Electrochimica Acta, vol. 178, pp. 240-248, 2015.

[12] D. A. H. Hanaor dan C. C. Sorrell, "Review of The Anatase to Rutile Phase Transformation", Intech, pp. 855-874, 2011.

[13] N. T. R. N. Kumara dan P.
Ekanayake, "Study of the Enhancement of Cell Performance of Dye Sensitized Solar Cells Sensitized With Nephelium lappaceum (F: Sapindaceae)", Journal of Solar Energy Engineering. vol. 135, no. August 2013, pp. 1-5, 2016 
Nurul Azmi: Pengaruh Penambahan Co-Doping Mg/La Terhadap Karakteristik $\mathrm{TiO}_{2}$ Sebagai Fotoelektroda 